\title{
Oblikoslovje v panonski narečni skupini ${ }^{1}$
}

\author{
Zinka (Terezija) Zorko \\ Univerza v Mariboru, Filozofska fakulteta, Koroška cesta 160, SI-2000 Maribor, \\ zinka.zorko@uni-mb.si
}

\begin{abstract}
SCN III/1 [2010], 5-17
V razpravi so predstavljeni oblikospreminjevalni in oblikotvorni vzorci $\mathrm{v}$ narečjih panonske narečne skupine $\mathrm{v}$ primerjavi s staro cerkveno slovanščino in slovenskim knjižnim jezikom ter s kratko analizo narečnega glasoslovja in naglasnih razmer. Obdelani so narečna sklonila in osebila; vsi trije spoli, zlasti slabo obstojni srednji spol; vsa tri števila, saj je dvojina dobro ohranjena. Nepregibne besedne vrste se med obravnavanimi narečji manj razlikujejo.
\end{abstract}

The article compares word-formation and morphological patterns of the Pannonian dialect group with those found in Old Church Slavonic and in Standard Slovene. It includes a brief analysis of the dialectal phonological and stress system, discussing the dialectal endings and inflections (the three genders, especially the relatively unstable neuter; and the three numbers, as the dual is well preserved). Non-finite word classes used in the Pannonian dialects investigated, however, show relatively little variation.

Ključne besede: oblikoslovje, oblikotvorje, sklanjatev, stopnjevanje, spregatev, spol, število

Key words: morphology, word-formation, declension, comparison, conjugation, gender, number

0 Po Logar-Riglerjevi Karti slovenskih narečij (1993) spadajo v panonski narečno skupino: prekmursko, goričansko (danes slovenskogoriško), prleško in haloško narečje. O teh dialektih so pisali številni dialektologi, tako npr. B. Raič, I. I. Sreznjevski, K. Ozvald, F. Ilešič, A. Pavel, S. Škrabec, V. Oblak, F.

\footnotetext{
${ }^{1}$ Prispevek je nastal v okviru raziskovalnega projekta J6-2238 z naslovom Slovenski jezik v stiku evropskega podonavskega in alpskega prostora, ki ga financira Agencija za raziskovalno dejavnost RS; odgovorni nosilec projekta je red. prof. dr. Marko Jesenšek.
} 
Ramovš, O. Asbóth, V. Novak, A. Vratuša, R. Kolarič, J. Rigler, T. Logar, M. L. Greenberg, F. Mukič, M. Koletnik, B. Rajh, Z. Zorko in drugi.

J. Rigler izvaja panonsko glasoslovje iz osnovnega panonskega sistema dolgih

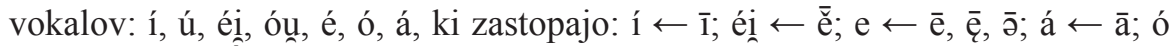
$\leftarrow \overline{\mathrm{Q}}$; óu $\leftarrow \overline{\mathrm{o}} ; \dot{\mathrm{u}} \leftarrow \overline{\mathrm{u}}$; ter kratkih vokalov: i, ù, ẹ, ọ, ə, e, o, a, ki zastopajo: $\mathrm{i} \leftarrow$

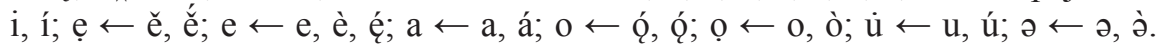

Prekmurščino navadno delimo na goričko, ravensko in dolinsko podnarečje; prleščino na spodnjeprleški, srednjeprleški, zgornjeprleški in kujleški govor; slovenskogoriško narečje na vzhodne in zahodne govore ter haloško na vzhodne, srednje ter zahodne govore.

Slovenska narečja so se v zgodovinskem razvoju najprej razdelila na jugovzhod in severozahod glede razvoja jata, ki se je razvil vzporedno z etimološkim o. V panonski narečni skupini sta se morala jat in dolgi etimološki o zgodaj zožiti in ozki e ter o sta se začela diftongirati v ei in ou kot na vsem jugovzhodnem delu slovenskega narečnega prostora.

V PNS so drugačni razvoji jata na vzhodu in zahodu Haloz ter v prleškem narečju.

Prleški monoftongični vokalizem dialektologi razlagajo različno. F. Ramovš navaja zgodovinske razloge, da je slovansko prebivalstvo nekdanje Kocljeve kneževine pobegnilo pred madžarskimi navali iz panonske pokrajine in si poiskalo zavetje za Dravo in v gozdovih na današnji nemško-štajerski in zahodno-ogrski meji. Po koncu madžarskih vdorov se je začelo naseljevanje od severozahoda, kjer sta se že razvijala ě v ei in ō v ou, drugi del pa izza Drave, iz Haloz in hrvaškega Zagorja ter je bil že dokaj kajkavsko niansiran.

J. Rigler in drugi pa oporekajo tej hipotezi, saj prleški monoftongi niso primarni in poenoglašanje diftongov poznajo na prehodih iz enega narečja v drugega tudi drugod. Ker se danes zelo ozka ẹ in o za jat in etimološki o ločita od srednje ozkih ẹ iz e, ę, b ter ọ iz nosnega o, kaže, da gre za mlajšo monoftongizacijo.

Naslednje skupne razvojne posebnosti PNS so: nepodaljšanje kratkih akutiranih nezadnjih zlogov. Ti so večinoma ostali kratki do danes. Dolgi polglasnik se je razvil v dolgi e-jevski fonem skupaj z etimološkim e in nazalnim e. Dolgi u se je v izgovoru začel pomikati naprej in se je zaokrožil v ü, sonantni 1 pa se je prek ou poenoglasil v u (v porabščini še ohranjeni ou v primerih gounčati za današnje gučati dokazuje razvoj sonantnega 1 prek ou v u). Ohranil se je tudi vokalični r.

Tako nastavimo osnovni panonski dolgi vokalni sistem: í, ù, ü, éi, óu, é, ó, á, v kratkem pa se pojavljata ozka ẹ in o ter široka e in o.

Konzonantizem v PNS je manj razčlenjen kot vokalizem. Razvil se je po značilnih slovenskih tendencah. Praslovanski dj v tipu *medja se je razvil v j, kasneje pa se je v prekmurskem goričkem in ravenskem podnarečju vsak j razvil v g, dj, dž, tj, g', k', verjetno pod madžarskim vplivom. Pri praslovanskem w je v PNS značilen razvoj v labiodental v, ki v izglasju ali v položaju pred nezvenečim soglasnikom izgubi zven in se izgovarja kot f. Trdi ł na koncu besede ima refleks -o, v prleščini tudi -a; morda pod vplivom štokavskih priseljencev. 
Palatalni l', r', n' so se razvijali po splošnih slovenskih tendencah: l' je otrdel, n' pa je vsaj v prekmurščini ohranjen; tu je ohranjena tudi sekundarna palatalizacija tipa vucje. Prehod izglasnega $-\mathrm{m} v-n$ je večinoma ohranjen.

V obdobju med 10. in 14. stoletjem se je formirala slovenska individualnost, hkrati pa tudi govori v panonski narečni skupini.

\section{Osnovni samoglasniški sestavi v obravnavanih narečjih}

\subsection{Prekmurski samoglasniški sestavi}

\section{Goričko podnarečje (tudi Gornji Senik)}

Dolgi: i:, ü:, u:; e:i, o:ư⿱ ẹ:, ọ:; a:, ror. Kratki naglašeni: i:, ü, u; ẹ, ọ; e; a; r.

\section{Števanovci}

Dolgi: i:, ü:/ü:i, u:; ẹ:, ọ:; ẹ:i, ọ:ư; a:i, a:ú, a:, + r. (Ozki e je nastal iz ē, ę, ə̄; ozki o je položajni iz eu + m'lọ:, z'jọ; diftong ẹ:i je nastal iz dolgega i:, ọ:u iz samoglasniškega ț:, a:i zastopa dolgi jat, a:u je iz dolgega etimološkega o in dolgega nosnega o.)

Ravensko podnarečje

Dolgi: i:/i:i, ü:/ü:i, u:; ẹ:, ọ:; ẹ:i, ọ:ư⿱ a:, + ro:

\section{Dolinsko podnarečje}

Dolgi: i:, ü:, u:; i:e; e:i, o:ư⿱ å:, + ror:. (Dolgi i:e je odraz za dolge è, ę, ō; a je pod vplivom prleščine rahlo zaokrožen.)

1.2 Prleško narečje ima osnovni dolgi samoglasniški sestav: i:, ü:, u:; ẹ:, ọ:; e्र:, o:; a:, + ro.. Refleks za dolgi jat je zelo ozki ẹ, za etimološki o in za nosni o dolgi, zelo ozki o, ozki e्र: zastopa ē, ę, ō, ozki o: dolgi a, dolgi a pa se govori le položajno, npr. pred -j - m'la:j. Pri kratko naglašenih samoglasnikih ozki ẹ zastopa akutirani jat, ozki o novoakutirani o, akutirani o in umično naglašeni o, kratki zelo široki e je odraz novoakutiranega e, akutiranega ę, kratkega polglasnika in umično naglašenih e in polglasnika.

1.3 Haloško narečje razpade na tri govore: vzhodni, srednjehaloški in zahodni haloški govori.

\section{Vzhodni haloški govori}

Dolgi vokali: i:, ü:, u:; ẹ:, ọ:; e:; a:, + ro:. Kratki vokali: i:, ü, u; ẹ, ọ; e; å; + ro . (Dolgi ozki ẹ zastopa dolgi polglasnik in dolgi jat (podobno kot v kajkavščini); široki e: dolgi nosni ę in dolgi etimološki e; dolgi ozki ọ je odraz dolgega etimološkega o: in dolgega nosnega o:. Kratki ozki e je odraz za akutirani jat, široki e pa za novoakutirani e, umično naglašeni e, novoakutirani polglasnik in 
akutirani nosni ę; ozki o zastopa akutirani nosni o, novoakutirani o in umično naglašeni o; kratki å je nastal iz akutiranega a.

\section{Srednjehaloški govori (Leskovec)}

Dolgi vokali: i:i, ü:i, u:ư⿱ ę:; e:i, o:u; (a:un); å:; + ro.. Kratki vokali: i:, ü, u; ẹ, ọ; e; å. Visoki vokali se diftongirajo, ozki ẹ: zastopa ę, ę, ō, diftong e:i je odraz za jat, diftong o:u je nastal iz dolgega ō, $\bar{Q}$, tudi à (ob n, m), zaokroženi å je odraz za dolgi à. Kratki ẹ je redek (za ə), široki kratki e zastopa akutirani polglasnik, akutirani ę in umično naglašeni e, ozki o je nastal iz akutiranih o in o ter umično naglašenega o.

Zahodni haloški govori (Žetale) izgubljajo razlikovanje kolikosti samoglasnikov. Dolgi vokali: i:, ü:, u:; i:e, u:o; ẹ:, ọ:; e:, o:; a:ư; a:; + ro. Nova diftonga i:e in u:o zastopata akutirani jat, akutirani polglasnik, umično naglašeni e, novo akutirani o, akutirani $Q$ in umično naglašeni o. Ozki ẹ: je odraz za dolge ē, ę, $\bar{\partial}$, ozki ọ za dolgi nosni o, široki e je nastal iz dolgega jata, diftong a:u zastopa dolgi etimološki o, široki o je nastal iz dolgega a.

\subsection{Slovenskogoriško narečje}

Zahodni slovenskogoriški govori (Zgornja Ščavnica) imajo samo dolge samoglasnike: i:, ü:, u:; i:e, u:o; ẹ:, ọ:; ie:/e:; e:i, o:u్ ; a:; + or. Diftong i:e zastopa akutirani jat, u:o akutirani in umično naglašeni o, ie: akutirana ę in e, umično naglašeni e, akutirani polglasnik, e:i je odraz dolgega jata, o:u pa dolgega etimološkega o in nosnega o, dolgi a pa a-jevske foneme.

Vzhodni slovenskogoriški govori (Črešnjevci) ločijo dolgi in kratki naglašeni vokalni sistem. Dolgi samoglasniki: i:, ü:, u:; ẹ:, ọ:; e:i, o:u; a:; + ro:. Kratki samoglasniki: i:, ü, u; ẹ, ọ; e; å; + ro. Dolgi ozki ẹ: je odraz za dolgi etimološki e, nosni ę in dolgi polglasnik, ozki o je redek, e:i zastopa dolgi jat, o:u dolgi etimološki o in nosni o, a je odraz za dolgi a. Kratki ozki e zastopa akutirani jat, ozki ọ akutirani nosni o in umično naglašeni o, kratki široki e je pogost fonem, saj zastopa akutirani ę, novoakutirani e, kratki polglasnik in umično naglašeni e. Kratki labializirani å je nastal iz akutiranega a tako kot v prekmurskem ravenskem podnarečju.

\section{Oblikoslovne katerogije spola, števila, sklonov, oseb in stopnje v PNS}

\section{$2.1 \mathrm{Spol}$}

Praslovanski princip razlikovanja sklanjatev po osnovah se je v historični dobi v glavnem zamenjal s principom razvrstitve po spolu. Indoevropščina je poznala tri spole: moški, ženski in srednji spol. Spol pri samostalnikih razberemo ali iz 
pomena - naravni spol - ali s pomočjo jezikovnega sredstva - slovnični spol. Spol je v slovanskih jezikih izražen s končnico kot formalnim, slovničnim sredstvom. Samostalniki moškega in srednjega spola vseh osnov so se osredotočili okrog trdega in mehkega tipa osnov na -o-; samostalniki ženskega spola na -a so ohranili svojo sklanjatev, osnove ženskega spola na - $\bar{u}$ in soglasnik so se osredinili okrog osnov na -i. Osnove na -a naravnega moškega spola se v slovenščini lahko sklanjajo po moški osnovi, prav tako hipokoristična imena in deminutivi (zlasti krstna imena in priimki, ki imajo zvezo z zvalnikom osnov na -a - npr. Sinko, Marko). Samostalniki srednjega spola na -o ali -e so v slovenščini razvili svojo sklanjatev in v PNS so sorazmerno dobro ohranjeni, vsaj $\mathrm{v}$ ednini, $\mathrm{v}$ dvojini in množini se lahko feminizirajo, podaljšani $\mathrm{s}$-t- in -n- se maskulinizirajo, podaljševanje osnov s -s- se je izgubilo.

V PNS je znan pojav t. i. oblik nadspola. V prekmurskem goričkem podnarečju na Gornjem Seniku uporabljajo ženske za 1. in 2. osebo ednine obliko moškega spola ('Jå 'san 'bẹjo.), prav tako v prleškem narečju v okolici Ormoža in v haloškem narečju na vzhodu (Veliki Vrh).

\section{2 Število}

Indoevropski jeziki razlikujejo tri števila: ednino, dvojino in množino. Dvojina se je $\mathrm{v}$ glavnem ohranila le $\mathrm{v}$ slovenščini in lužiščini, in to $\mathrm{v}$ oblikah za imenovalnik - tožilnik, dajalnik - orodnik. V PNS je dvojina ohranjena v vseh narečjih.

\subsection{Skloni}

Indoevropščina je imela osem sklonov, praslovanščina jih je obdržala, v slovanskem razvoju je ablativ glasovno sovpadel z genitivom, $v$ slovenščini se je vokativ ohranil v Brižinskih spomenikih, osebnih imenih (Tone), sicer pa $\mathrm{v}$ posebni intonaciji (ọ́če - ôče) z dolgim cirkumfleksom.

\subsection{Sklanjatve}

\section{1. moška sklanjatev}

Vzorec za staro cerkveno slovanščino: ednina - rabъ, raba, rabu, rabъ, rabe, rabě, rabomъ; dvojina - 1., 4., 5. raba, 2., 6. rabu, 3., 7. raboma; množina - 1., 5. rabi, rabъ, rabomъ, raby, raběhъ, raby. Mehka sklanjatev: vrač -ъ, -a, -u, -ь, -i, -emь; -a, -u, -ema; -i, -ъ, -emъ, -e, -ihъ, -i. Današnji slovenski knjižni ustrezniki: korak -ø, -a, -u, -ø, -u, -om; -a, -ov, -oma, -a, -ih, -oma; -i, -ov, -om, -e, -ih, -i.

V panonski narečni skupini so vzorci moških sklanjatev naslednji (PR prekmursko narečje, $\mathrm{P}$ - prleško narečje, $\mathrm{SG}$ - slovenskogoriško narečje, $\mathrm{H}$ - haloško narečje): 
- PR: b'råt -ø, -a, -i, -a, -i, -on; -a, -of, -oma, -a, -oma, -oma; -i, -of, -on, -e, -aj, -ami.

- P: b'rat -ø, -a, -i, -a, -i, -on; -a, of, -oma, -a, -oma, -oma; -i, -of, -on, -e, -ix, $-\mathrm{i}$.

- SG: b'rat -ø, -a, -i, -a, -i, -on; -a, -of, -oma/-ama, -a, -ax, -oma/-ama; -i, -of, -an, -e, -ax, -ami.

- H: b'rat -ø, -a, -i, -a, -i, -on; -a, -of, -an/-on/-ama, -ax, -ama; -i, -of, -on/-an, -e, -ax, -ami.

Povsod je v dajalniku in mestniku ednine končnica -i, $v$ orodniku ednine -on (tudi za c, j, ̌̌ , ž, š), v P in PR je v dajalniku, mestniku in orodniku dvojine končnica -oma; v mestniku množine je v PR, SG in H končaj -ah $\rightarrow$ PR v -aj, v orodniku množine pa -ami; le v P -ih, -i.

Znano je podaljševanje osnove z -je/-ovje v množini: možljẹ:, b'råtje, zo'bouje/ zo'bouvge, k'metovje.

Znani so tudi premični, mešani in končniški naglašni tip: 'jezik/jelzika/'gezik; 'vọ:s, vo'za: (v Porabju, v Števanovcih, se pri mešanem naglasnem tipu v dajalniku in mestniku ednine pojavlja refleks za naglašeni jat: sve'ta:i); v'ra:k vra'ga, v'ragi, vra'go:uvdje (PR); 'pes, p'så ('pesa, 'pesi/p'sovi). Le na zahodu Haloz, v Žetalah, se pojavljajo v množini končnice -en, -ex, -emi iz zaimenske sklanjatve. Samostalnik 'dẹca je v imenovalniku množine moškega spola ('Dẹca so se šlpilali.), sicer pa se sklanja po edninski ženski sklanjatvi (De'cẹ ni do'ma:.).

\section{1. ženska sklanjatev}

Vzorec za staro cerkveno slovanščino

Trda sklanjatev: ednina - žena, ženy, ženě, ženo, ženo, ženě, ženojo; dvojina 1., 4., 5. ženě, 2., 6. ženu, 3., 7. ženama; množina: 1., 4., 5. ženy, ženъ, ženamъ, ženahъ, ženami.

Mehka sklanjatev: ednina - duša, duše, duši, dušo, duše, duši, dušejo; dvojina - 1., 4., 5. duši, 2., 6. dušu, 3., 7. dušama; množina - 1., 4., 5. duše, dušb, dušamъ, dušahъ, dušami.

Vzorec za slovenski knjižni jezik: žena, -e, -i, -o-, -i, -o; -i, -ø, -ama, -i, -ah, -ama; -e, -ø, -am, -e, -ah, -ami.

V PNS so vzorci:

- PR: 'ra:ǔnz-a, -e, -i, -o, -i, -ov; -i, -i/-ø, -ama, -i, -aj, -ama; -e, -ø/-e, -an, -e, -aj, -ami. Mešani naglasni tip: 'ra:uيka, ro'tẹ:, ro'ta:i, ro'ka:u, ro'ta:i, ro'ta:ưv (Števanovci). V dajalniku in mestniku je a:i refleks za dolgi jat. Končniški naglasni tip: 'miegla, mag'lẹ:, mag'la:in, mag'la:u, mag'la:i, mag'la:uv (Števanovci).

- P: 'lip-a, -e, -i, -o, -i, -oj; -i, -ø, -ama, -i, -ax, -ama; -e, -ø, -an, -e, -ax, -ami. Mešani naglasni tip: 'žena, že'ne्र:, 'ženi, že'nọ:, 'ženi, z že'nọ:j. Tako se sklanja tudi 'mati, mate're्र:.

- SG: 'lip-a, -e, -i, -o, -i, -oj; -i, -ø, -oma, -i, -ax, -oma; -e, -ø, -an, -e, -ax, -ami. Mešani naglasni tip je tak kot v prleščini: g'låva, gla'vẹ:. 
- H: 'lip-a, -e, -i, -o, -i, -on; -i, -ø, -ama, -i, -ax, -ama; -e, -ø, -an, -e, -ax, -ami (Žetale: 'lip-a, -e, -i, -o, -i, -i; množina: 'lip-e, -ø, -en, -e, -ex, -emi; e je nastal iz jata).

\section{2. ženska sklanjatev}

Vzorec za staro cerkveno slovanščino: ednina - kostь, kosti, kosti, kostь, kosti, kosti, kostijǫ; dvojina - 1., 4., 5. kosti, 2., 6. kostiju, 3., 7. kostıma; množina 1., 4., 5. kosti, kostii, kostьmъ, kostьhъ, kostьmi. Vzorec za slovenski knjižni jezik: nit-ø, -i, -i, -ø, -i, -jo; -i, -i, -ima, -i, -ih, -ima/-ma; i, -i, -im, -i, -ih, -mi. Mešani naglasni tip: kóst, kostí, kósti, kóst, kósti, kostjó; -í, í, -éma, -í, -éh, -éma; -í, -í, -ém, -í, -éh, -mí.

V PNS je sklanjatev samostalnikov ženskega spola brez končnice takale:

- PR: 'miš-ø, -i, -i, -ø, -i, -jov; -i, -i, -ama, -i, -ama, -ama; -i, -i, -ån, -i, -aj, -ami. Mešani naglasni tip: 'no:ǔč, no'či:, z nočljo:uv. Po tej sklanjatvi se sklanja 'krff, krọ'vi:, s króó:uvv, pa tudi samostalniki na -ev: 'tikef, tikvi; 'cẹrkef, 'cẹrkvi; 'či:, 'če:i̊ri; čerljo:ưv.

- P: 'nit-ø, -i, -i, -ø, -i, -joj; -i, -i, -ma; -i, -i, -im, -i, -ix, -mi; mešani naglasni tip: 'pěx̌, pe'či:, s pečljọ:j, -i:, -i:, -ẹ:n, -i:, -ẹ:x, -'mi:.

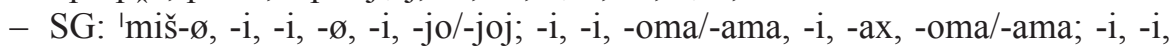
-am, -i, -ax, -ami. Kaže se vpliv ženske a-jevske sklanjatve, zlasti v zahodnem delu.

- H: 'miš-ø, -i, z mišjon; s kost'jo:ưj (vzhod); z 'mi:ši, s 'ka:uيnsti (zahod; iz -oj); ko'ka:ữ̌en, ko'ka:ựšex, ko'ka:ǔšemi (Žetale).

\section{Samostalniki srednjega spola}

Vzorec iz stare cerkvene slovanščine

Trda sklanjatev: ednina - lěto, lěta, lětu, lěto, lěto, lětě, lětom; dvojina - 1., 4., 5. lětě, 2., 6. lětu, 3., 7. lětoma; množina - lěta, lětъ, lětomъ, lěta, lěta, lětěhъ, lěty.

Mehka sklanjatev: ednina - Qže, Qža, Qži, ože, ože, ožzi, фžemь; dvojina - 1., 4., 5. Qži, 2., 6. Qžu, 3., 7. Qžema; množina - 1., 4., 5. Qža, Qžb, Qžemъ, Qžihъ, Qži. Vzorec za slovenski knjižni jezik: let-o, -a, -u, -o, -u, -om; -i, -ø, -oma, -i, -ih, -oma; -a, -ø, -om, -a, -ih, -i.

Prekmurščina: 'lẹt-o, -a, -i, -o, -i, -on; -i, 'le:în, 'lẹtoma, -i, -oma, -oma; 'le:ita (so bi'le:i ), -ø, -on, -a, -aj, -ami. Znan je tudi mešani naglasni tip: ne'bo:u, ne'ba:, 'nebi. Podaljševanje osnov z -n- in -t- je ohranjeno, izgubilo pa se je podaljševanje s -s-: b'reme, bre'mẹna; 'tele, te'leta; d're:ívo, d're:iva. Samostalniki tipa 'gẹ:tra, p'lü:ča so ženskega spola.

Zaradi tematskega -a- v množinskih končnicah se je v prekmurščini v imenovalniku množine -a ohranil, veže pa se z ženskimi glagolskimi in pridevniškimi oblikami.

V ednini ohranjajo snovna, skupna in pojmovna imena srednji spol.

$\mathrm{V}$ prleščini je srednji spol dobro ohranjen, le v množini se lahko pojavi feminizacija: 'prsa, -ø, -an, -a, -ax, -ami.

SG: oblike srednjega spola so lahko ohranjene le v ednini: 'lẹt-o, -a, -i, -o, -i, -on; -i, -ø, -ama/-oma, -ax, -ama/-oma; 'le:it-e, -ø, -an, -e, -ax, -ami. Mešani 
naglasni tip: tes'to:u, tes'ta: je še pogost. Samostalniki, ki podaljšujejo osnove s -t- ali z -n-, prehajajo med samostalnike moškega spola: 'tele, te'leta; dv. te'leta, mn. te'leti; 'sẹmen, 'semna, 'sẹnni.

H: na vzhodu in na zahodu je sklanjatev srednjega spola ohranjena v ednini: 'lẹto, dv. 'lẹti, mn. 'le:ite; Žetale: 'li:eto, 'li:eta; 'li:eti, 'le:te, -ø, -en, -e, -ex, -emi.

\section{Pridevniška sklanjatev}

V stari cerkveni slovanščini se je razlikovala sklanjatev nedoločnega pridevnika od določnega.

V PNS je ohranjena le sklanjatev po vzorcu določne, pa tudi oblika z -i je prevladala $\mathrm{v}$ vseh štirih narečjih; v prleščini in prekmurščini imajo pridevniki na -en še nedoločno obliko: s'rečen, ž'meten, 'betežen, drugi pa le določno: 'nisiki, 'šürki, g'lọboki.

Sklanjatev določnih pridevnikov v stari cerkveni slovanščini je bila sestavljena: novyi, novoje, novaja - novajego, novyję.

V prekmurščini je sklanjatev prevzeta iz stare trde zaimenske: ta, toga.

Tako je prekmurski sklanjatveni vzorec za moški spol: 'le:ipi, 'le:ipoga, 'le:ipomi, 1. ali 2., 'le:ipon, 'le:ipin; 'le:ipiva, 'le:ipi, 'le:ipima, 'le:ipiva, 'le:ipima, 'le:ipima; 'le:ipi, 'le:ipi, 'le:ipin, 'le:ipe, 'le:ipaj, 'le:ipimi. Končni -h v rodilniku dvojine in množine onemi, v mestniku množine je končnica -aj nastala iz -ah po onemitvi končnega -h. Vzorec za ženski spol: 'le:ip -a, -e, -oj, -o, -oj, -of; 'le:ip-ivi, -i, -ima, -ivi, -ima, -ima; 'le:ip-e, -i, -in, -e, -aj, -imi. V dvojini se pritakne v imenovalniku končaj -va/-vi, verjetno iz števnika dva.

V prleščini je sklanjatveni vzorec za moški spol: 'lẹ:p-i, -ega, -emi, 1. ali 2. -en, -in; -a, -ix, -ima, -a, -ima, -ima; -ix, -im, -e, -ix, -imi; za ženski spol: 'lẹ:p-a, -oj, -o, -oj, -oj.

V Slovenskih goricah in v Halozah je pridevniška sklanjatev enaka kot v prleščini, le v rodilniku ednine se pojavlja poleg -ega tudi končnica -iga.

Stopnjevanje v PNS je blizu knjižnemu, z obrazili -ši, -ji, -ejši in opisno, presežnik se tvori z naj- ali nar- in obliko primernika: 'šürši, 'vočišis, 'nar'šürši, bole g'lopki (prekm.).

\section{Zaimki v panonski narečni skupini}

Za knjižno 'kdo', stcsl. kъto, so znane oblike v prekmurščini: š'tọ, 'kọga, 'kọmi, 'kọga, p'rikọn, s 'kọn; v prleščini: š'tọ:/g'dọ:; v SG: š'to/g'do:ứ; v Halozah: 'da:u/g'do:u, 'ku:oga, 'ku:omi (Žetale).

Za knjižno kaj, stcsl. čbto - česo, so znane oblike v prekmurščini: 'kå, 'česa, 'čemi, 'kå, p'ričen, s 'čin; v prleščini: 'kej, 'česa; v SG: 'kåj/'kå; v haloškem narečju: 'kå, 'čẹsa.

Vprašalna zaimka sta torej š'tọ/g'do:ụ in 'kå/kåj/'kej. 
Osebni zaimki so v prekmurščini: 'ges/'ge/ljes, me'nẹ:; prleško: 'jas/lje, 'mene; v SG: 'ja:s, 'mie:ne; haloško: 'jås, 'mene, z 'mẹni.

Primeri za prekmurske oblike osebnih zaimkov: 'gäs/'ge - me'nẹ:; 'ti: - te'bẹ:; 'un - n'jega; 'una - n'jẹ:; 'müva - 'müvi (ž. sp.) - 'naja; 'vüva -'vaja; 'unadva n'jiva; 'mi: - 'nas; 'vi: - 'vas; 'uni - n'ji:.

Prleške oblike: 'jas/'ja - 'mene; 'ti - 'tebe; 'un - 'jega; 'una - 'jẹ; 'ovo - 'ovega 'on'; 'mi: - 'no:s; 'vi: - 'vo:s; 'uni - 'jix; dvojina: 'mi:ja/'mi:je (ž. sp.), 'no:j, 'vi:ja - 'vo:j; 'ọvid'vo: - 'jẹ:dva. Povratni osebni zaimek se ima v orodniku obliko 'sọboj.

Slovenske gorice: 'ja:s - 'mie:ne, 'ti: - 'tie:be; ' u:n/'u:ovi - 'je:ga, 'u:na - 'jẹ:; 'vi:ja/'vi:jad'va:, 'mi:ja/'mi:jad'va:, 'u:ovad'va: - 'u:ovixd've:ix, 'mi: - 'nas, 'vi: - 'vas, 'u:ovi - 'u:ovix.

Haloze: 'jås - 'mene - z 'meni; 'ti: - 'tebe - s 'tebi; 'u:on - 'jẹga; 'u:ona - 'jẹ - ž 'jo:j; 'mi:ja - 'no:ji; 'vi:ja - 'vo:j; 'u:ond'vo:/o'ni:ja.

Za dvojinske oblike so tipične okrajšave za dva: 'müva/'mi:ja. Za on se uporablja tudi oblika kazalnega zaimka ovi.

\section{Pridevniški zaimki}

Svojilni zaimki (prekmurščina): 'mọj, 'mọja, 'mọje, 'mo:jega; t'vọj - t'vọjega; n'jegof; 'nåjni, 'vajni, 'nåš, 'våš, n'jixof, s'vọj.

Prleščina: 'mọj, t'vọj, 'jegof, 'je्र:ni, 'najin/'nadvin, 'vajin/'vadvin; 'je:dvin, 'njun, 'naš, 'vaš, 'jixof.

Slovenske gorice: 'mọj - 'mọ:jiga; t'vọj - t'vọjiga; 'jegof, 'jẹ:ni; 'naš, 'våš, 'jixof.

Haloze: 'mu:oj - 'mu:ojga, t'vu:oj, 'jẹ:gof, 'jẹ:nin, 'no:jin, 'vo:jin, od 'ji:ji, 'nåš, 'våš, 'ji:xof (Žetale).

\section{Kazalni, vprašalni, oziralni in poljubnostni zaimki}

Prekmurščina: 'tẹ:, 'toga, 'tomi, 1./2. pr'tọn, s'tẹ:n; ž. sp.: 'ta:, 'tọ:j, s'to:uff; 'tisti, 'ovi, 'tåkši; šlteri, 'kåkši, 'ništerni 'nekateri'.

Prleščina: 'te्र:, 'ta:, 'tọ: - 'toga, 'temi, p'riten, s 'tẹ:n; ž. sp.: 'ta, 'te, 'tọj; v poudarjenem položaju v stavku se uporablja 'tọti, 'tọta, 'tọto; 'tisti, 'ovi, 'taki, 'takši, 'te्र:ki 'tolik'; 'kåkši, 'kẹ:ri, 'kerište 'kateri koli', 'kakšište, marsi'ke्र:ri.

Slovenske gorice: 'tu:oti/'tọti, 'ti:sti, 'u:ovi/'u:oni, 'tåki, 'tåkši, 'ka:ki, 'kåkši; 'kẹ:ri, k'tẹ:ri, 'nẹki, 'nekši, 'ne:ikini 'nekateri'.

Haloze: 'tu:oti, 'ta:u, 'ti:sti, 'u:oni, 'to:k, 'ki:eri, 'ko:k, 'ka:uِvi, či'ga:uِ (Žetale).

\section{4 Števniki}

\section{Glavni števniki}

Prekmurščina: 'eden/'en, 'enoga, 'ena - 'enoj; d'va:, d'vẹ:j, d'vöma; t'rije/tro'gẹ: t'rẹj, š'ti:ri, 'pẹ:t, 'šẹ:st, 'seden, 'ọsen, de'vẹ:t, de'sẹ:t, d'våjsti, t'rẹ:sti, š'tirdese'tena, s'to:u, 'gezero. 
Posebni obliki sta za 20 in 30, od 40 naprej se enice zapostavljajo za deseticami.

Podobne oblike se pojavljajo tudi v Slovenskih goricah. V prleščini in v Halozah se po obliki števniki ne ločijo od knjižnih.

Vrstilni števniki so v PNS podobni: 'pr:vi, d'rü:jgi, t'rẹ:či, š'törti, 'pẹ:ti (Prekmurje), le oblika t'rẹ:či iz *tretji je samo prekmurska.

Ločilni števniki v PNS niso znani.

\section{Glagol}

V PNS so se razvili vsi glagolski oblikotvorni in oblikospreminjevalni vzorci, kakršne poznamo v knjižnem jeziku. Manj pogost je le predpretekli čas in redke so tudi deležijske in deležniške oblike, največ jih je ohranjenih v prekmurščini.

\section{Sedanjiška spregatev}

Vzorec iz stcsl. za tematske glagole: nesǫ, neseši, nesetъ; nesevě, neseta, nesete; nesemъ, nesete, nesǫtъ; za atematske glagole: jesmъ, jesi, jestъ; jesvě, jesta, jeste; jesmъ, jeste, sọtъ.

Slovenski knjižni jezik - tematska spregatev: nes-em, -eš, -e; -va, -ta, -ta; -mo, -te, -jo; atematska spregatev: sem, si, je; sva, sta, sta; smo, ste, so.

Prekmurščina (vsi glagoli se spregajo po tematičnem vzorcu): nelsẹ:n, nelsẹ:š, ne'sẹ:; nelsẹ:va (m. sp.), ne'sẹ:ve (ž. sp.), ne'sẹ:ta, ne'sẹ:ta; ne'sẹ:mo, ne'sẹ:te, ne'se:jo; 'sån, 'si, 'je; s' vå/s've, s'tå, s'tå; s'mo, s'te, so (znane so tudi poudarjene oblike: 'jeste, ljestejo); spregatev glagola biti v prihodnjiku v nenaglašenem položaju: mo, boš, de; va/ve, ta, ta; mo, te, do.

Oblike deležnika na -1 glagola biti: 'bi:un, 'bi:ila, bi'lo:u, billi:, bi'lẹ:. Oblike z naglašenim osebilom prevladujejo v (stari) 1. glagolski vrsti; ohranjeno je osebilo -va v 1. osebi dvojine za moški spol in -ve za ženski spol. Velelnik ima oblike: 'nesi, 'nesiva/'nesive, 'nesimo, 'nesite; 'dẹlaj - 'dẹlajva.

Nedoločnik se končuje na -ti (nesti) in -čti (pečti). Nedoločniška pripona -no- $\leftarrow$-no- je ohranjena: z'dignoti. Namenilnik na -t in -čt je ohranjen in se veže s samostalnikom $\mathrm{v}$ rodilniku.

Deležnik na -ł ima končaj -o, v dolinskem podnarečju tudi -u: 'neso/'nesu.

$\mathrm{V}$ prleščini in v Slovenskih goricah so oblike blizu knjižnim. V 1. osebi dvojine se poleg osebila -va govori tudi -ma; atematični glagoli se spregajo po tematičnem vzorcu: 'do:ta, 'vẹ:te, 'jẹ:te. Nedoločnik se končuje na -ti/-čti, namenilnik na $-\mathrm{t} /$-čt in se veže s predmetom v rodilniku. Deležnik na -ł se praviloma končuje na -a (vpliv priseljencev iz Hrvaške), na vzhodu tudi na -o: 'nesa/'neso.

Haloški govori se od drugih ločujejo po posebnem osebilu -do za 3. osebo množine na vzhodu: 'nesedo, p'rosido, 'delado (ali po analogiji z atematičnimi glagoli: bodo, vedo, jedo, gredo ali pa gre za hrvaški vpliv). Ohranjena je ena atematična oblika: 've:sta : 've:ste (Žetale). V Porabju, v vzhodni prleščini in v 
vzhodnih Halozah uporabljajo ženske v 1. in 2. osebi ednine glagolske oblike za moški spol: sun 'dẹlo (ženska).

V vsej PNS se govorijo deležja: sto'jẹ:, po'dọ:čki, 'bi:fši, bi'žečki, le'žečki, si'dečki (prekm.) in deležniki: ž'gẹ:č, 'vroč, no'sẹ:ča, pi'kẹ:ča 'ro:ứža.

\section{Prislov}

V prislovnih oblikah najdemo veliko arhaičnih osnov, največ v prekmurščini: na'šerci 'na široko', na'lejci 'na lahko', na'tẹ:nci 'na tanko', 'nindri 'nekje', 'indri 'drugje', pr'le 'prej', 'kelko, 'telko, 'se/'esi 'sem', ot'kẹ:c 'od kod', 'inda 'nekoč', v'gọjno 'rano', g'nes'dẹ:n 'dandanes', na sp'rọtolge 'na pomlad', 'våči 'drugače', 'trno 'zelo', 're:insan 'res', 'eti 'tu'.

\section{Predlogi}

Predlogi bistveno ne odstopajo od knjižnih.

\section{Vezniki}

Povsod v PNS opravlja ka funkcijo veznika da. Ohranjen je veznik no iz ino 'in'; ninč 'niti', liki 'ampak' (prekm.), ováči, 'venda, 've 'saj' (prleščina), 'neičč-'neičc.

\section{9 Členki}

Členki se po narečjih razlikujejo: 'gẹli ‘jeli', 'vẹj 'saj', 'pa:, 'ba:r 'samo', 'våči, 'lekar 'baje', 'ešče ‘še' (Prekmurje); pre, kar ne 'ne', 'vi:ena ‘menda', leki ‘mogoče' (Slovenske gorice); 'morti ‘morda', 've ‘saj’ (prleščina).

\section{Medmeti}

Medmeti izražajo človekovo razpoloženje, posnemajo naravne šume in gibe, velevajo, prepovedujejo in zapovedujejo. Za vzorec bodo navedeni najpogostejši medmeti v slovenskogoriškem narečju.

Razpoloženjski medmeti: o'jọ:j, a'xa:; zvalniki svetopisemskih oseb, zlasti Jezus in Marija: 'Jẹ:žoš, Ma'ri:ja; Ma'dọ:na, 'bo:unk po'ma:ge, 'bo:ưg ne 'da:j, za 'bọžjo 'vọlo.

Zmerjavke in kletvice: 'sa:tan, xu'di:č, v'ra:k, 'lü:cifer, prek'lẹ:to, prok'lẹ:manski 'ta:jfl, 'pọrka ma'dọ:na, je'bẹ:nti, 'pi:ši me v 'rit.

V prekmurščini je znan še grozilni medmet: Palru:n te v'da:ri. 
Posnemovalni medmeti posnemajo šume v zvezi s človekom: 'xa: 'či:, 'ju:xu'xu:; v zvezi z živaljo: m'ja:un, 'ki:kiri'ki:, 'mu:, 'xo:ư⿱ okoljem: 'čọf, čr'bu:nk, 'pi:ka-'pọk.

Z velelnimi medmeti vzpostavljamo stik s človekom ali živaljo. Zvalnice in pozdravi: 'du:ọber ve'čẹ:r (Haloze: 'dọbro ve'čer); 'bo:ugg 'da:j, z'bo:ưgon, 'bo:ưk 'da:j s'ri:ečo; 'bo:unk 'žie:gne, 'bo:ưk 'lọ:ne, 'bo:unk de: 'tå:1 s'vẹ:tix 'meš. Velelnice za žival: s'tü:ja (desno), 'xu:op (levo); za konja: 'vi:st (na levo), 'dübo (na desno), 'jẹ: (obstani). Vabni klici za živali: 'mu:jc 'mu:jc, 'pi: 'pi: 'pi:.

\section{LITERATURA}

Mihaela KOLETNIK, 2001: Slovenskogoriško narečje. Maribor: Slavistično društvo Maribor. (Zora 12.)

Tine LOGAR, 1996: Dialektološke in jezikovnozgodovinske razprave. Uredila Karmen Kenda - Jež. Ljubljana: ZRC SAZU.

Rajko NAHTIGAL, 1952: Slovanski jeziki. Ljubljana: DZS.

Martina OROŽEN, 1996: Poglavja iz zgodovine slovenskega knjižnega jezika. Ljubljana: Filozofska fakulteta.

Fran RAMOVŠ, 1952: Morfologija slovenskega jezika. Ljubljana: DZS.

Jakob RIGLER, 2001: Izbrani spisi 1. Jezikovnozgodovinske in dialektološke razprave. Ljubljana: ZRC SAZU.

Zinka ZORKO, 1998: Haloško narečje in druge dialektološke študije. Maribor: Slavistično društvo Maribor. (Zora 6.)

\section{MORPHOLOGY OF THE PANNONIAN DIALECTAL}

The paper presents the morphology of the Prekmurje, Prlekija, Haloze and Slovenske gorice dialects from synchronic and diachronic perspectives. A brief analysis of their phonology and vocabulary is also included. A comparison of these dialects with Old Church Slavonic and other Slavic languages reveals many similarities in their morphological evolution, while the results show that this took place more slowly in these dialects owing to the centuries-long separation of Prekmurje from the central Slovene region and to the influence of the neighboring Styrian dialects in the west. Nominal declensions are classified according to gender, while the endings may be leveled, and the dual is retained. The Prekmurje dialect preserves neuter gender nouns in the plural, while the -t-, -n- and -s- in other dialects become masculine in the dual, and all other nouns may become feminine in the singular. With the exception of the stress on endings, all stress types in the nominal declension are well preserved. A typical Prekmurje ending of the type nesén is found in Prekmurje verb conjugation. The masculine nominal declension has a dialectal - $\mathrm{i}$ - in the dative and in the locative of the singular as well as -e from yat 
in the Prekmurje dialect. The instrumental of feminine declensions in these dialects is -o/-oj/-i -on/-ov. The Prekmurje dialect preserves the hard adjective declension and, in verb conjugation, the endings -va and -ve for the $1^{\text {st }}$ person of the dual of masculine and feminine. As for non-finite parts of speech, the most productive are adverbs, particles and interjections, while prepositions and conjunctions (except for ka instead of da) are close to those in the literary language. 